\title{
BIOSORPTION OF IRON FROM AQUEOUS SOLUTION BY DRIED SPIRULINA PLATENSIS AND CHLORELLA VULGARIS

\author{
Entesar A. Ahmed
} \\ Botany and Microbiology Department, Faculty of Science, Al-Azhar University (Girls Branch), Cairo, Egypt.
}

\begin{abstract}
The present investigation shows that substantial amount of iron ions biosorption from aqueous solution onto the biomass of dried cells of blue green alga Spirulina platensis and green alga Chlorella vulgaris at different iron concentrations. The IR analysis for surface function group of algal biomass revealed the existence of amino, carboxyl, hydroxyl and carbonyl groups, which are responsible for the biosorption of iron. Also, the results of scanning electron microscope analysis suggested that the biomass of $S$. platensis and $C$. vulgaris are an extremely efficient biosorbent for the removal of iron from aqueous solutions.
\end{abstract}

Key Word: Biosorption; IR analysis; Scanning Electron Microscope analysis; Spirulina platensis and Chlorella vulgaris.

\section{Introduction}

The production of metals has rapidly increased since the industrial revolution. Some metals usually form compounds that can be toxic carcinogenic or mutagenic even in very low concentrations (Picardo et al., 2009). Iron is commonly found in rocks and soil. Under proper conditions, iron will leach into the water resources from rock and soil formations. Exceeding iron concentration greater than $0.3 \mathrm{mg} / \mathrm{L}$ causes water staining that adversely affect plumbing fixtures, dishware, clothes and produce a yellow to reddish appearance in water. These levels may also impart taste and odor of drinking water. The US Environmental Protection Agency (USEPA) has established a secondary drinking water regulation of $0.3 \mathrm{mg} / \mathrm{L}$ for iron (EPA, 2000; Ncibi et al., 2007).

Conventional techniques for metal removal from aqueous solutions include chemical precipitation, ion exchange, adsorption process, membrane process, crystallization and electrochemical treatment. Considering the cost, technical complexity and limitations of the conventional methods make the alternative biological methods more appealing (Schiewer and Volesky, 1995). Biological process for metal ions removal from aqueous solutions can be divided into three general categories: (a) sorption of metal ions onto the surfaces of a microorganism, (b) intracellular uptake of metal ions, and(c) chemical transformation of metal ions by microorganisms. The latter two processes require live organisms to proceed (Holan and Volesky, 1994; Mamisahebei et al., 
2007). Sorption of heavy metals by various biological materials has been proposed as an efficient and potentially cost effective tool for metal enriched industrial effluents. Biosorption can be defined as the removal of metal or metalloid species, compounds and particulates from solution by biological material (Gadd, 1993).

Biosorption is a property of certain types of inactive, dead microbial biomass to bind and concentrate heavy metals from very dilute aqueous solutions (Gaur and Dhankhar, 2009).Capability of microorganisms to bind heavy metals in aqueous solutions has long been of scientific interest (Aksus and Gulen, 2002; Sen and Ghosh Dastidar, 2007).

Various biomasses such as bacteria (Iyeret al., 2005), yeast (Tunali $\boldsymbol{e t}$ al., 2006; Anayurt et al., 2009) and algae (Gupta and Rastogi, 2008 a, b and 2009) were investigated as biosorbent for the removal of heavy metals. The most important criteria for developing algal biosorbents to decrease harmful metal contents in soil and water are the followings: ability for rapid adsorption of huge amounts of metal ions, availability in large quantities because of worldwide cultivation and relatively cheap production (Solisio et al., 2006; Abu Al-Rub et al., 2006). Spirulina and Chlorella cells were used by many researchers to test their ability to remove heavy metal ions from polluted water (Gokhale $\boldsymbol{e t}$ al., 2008; Çelekli et al., 2010). The use of various conditions for the adsorption resulted in different adsorption properties. Mehta and Gaur (2001) compared the different adsorption features of living and dead biomass of Chlorella vulgaris cells and stated that the use of dead biomass is favorable because it tolerates high concentrations of toxic ions, a nutrient supply unnecessary and the culture conditions are not limiting. Blue-green algae including, Spirulina (Arthrospira), Nostoc, Anabaena, and Synechococcus were the typical examples that showed the potential as biosorbent for efficient removal of heavy metals from wastewaters (El-Sheekh et al., 2005).

Cyanobacteria have some advantages over other microorganisms including their greater mucilage volume with high binding affinity, large surface area, and simple nutrient requirements (Roy et al., 1993). Cyanobacteria are easily cultivated in a large scale in laboratory cultures providing a low cost biomass for the biosorption process. Several algae were tested for their ability to a adsorb heavy metals.

The aim of the present work was to study the removal of iron from solutions by using dead Spirulina platensis and Chlorella vulgaris biomass.

\section{Materials and methods}

\section{Algal samples}

Spirulina platensis and Chlorella vulgaris dry material were obtained from Algae Unit at National Research Center. 
Biosorption of Iron from aqueous solution by dried Spirulina platensis and Chlorella vulgaris

\section{Preparation of iron solution}

Metal salt used in the preparation of the synthetic metal bearing solutions were $\mathrm{FeSO}_{4}$ at different concentrations100, 150, 200,300 and 400ppm. Deionized water was used in all experiments.

\section{Analytical methods}

\section{Determination of metals concentrations}

The concentrations of metals in all samples were determined according to the (APHA, 2005) method using Atomic Absorption Spectrometer (Varian Spectra AA 220, USA) with graphite furnace accessory and equipped with deuterium arc background corrector. Precision of the metal measurement was determined by analyzing the metal concentration of all samples (at the Regional Center of Mycology and Biotechnology, Cairo, Egypt).

\section{Batch biosorption experiments}

General uptake procedure experiment was carried out in $250 \mathrm{ml}$ conical flask containing100ml of different concentrations of 100, 200, 300 and 400ppm of $\mathrm{FeSO}_{4}, 1 \mathrm{~g}$ of biomass was introduced into conical flask. The flask was sealed with rubber cork. Then the flask was kept in rotary shaker with an agitation rate of 200rpm for 24h. Then it was filtered with the help of Whatmann no.1 filter paper. Filtered sample was analyzed for concentration of heavy metal in atomic absorption spectroscopy. To distinguish between possible metal precipitation and actual metal sorption, controls (blank) were used without biosorbent materials.

The percent biosorption of metal ion was calculated as follows:

$$
\text { Biosorption }(\%)=\frac{C i-C f x 100}{C i}
$$

$\mathrm{Ci}=$ initial concentration

$\mathrm{Cf}=$ final concentration

All the experiments were carried out in triplicate and the mean of the quantitative results were used for further calculations. For the calculation of mean value, the percent relative standard deviation for results was calculated and if the value of standard deviation for a sample was greater than $5 \%$, the data were discarded.

\section{Effect of pH on biosorption}

The batch experiment was carried out by contacting $0.1 \mathrm{~g}$ of alga with $100 \mathrm{ml}$ of $50 \mathrm{mg} / \mathrm{L}$ of metal solution in $250 \mathrm{ml}$ stopper conical flask at different $\mathrm{pH}$ value, ranging from 2 to 8 . The $\mathrm{pH}$ of the solutions was adjusted either by hydrochloric acid or sodium hydroxide. The mixture was shaken for $2 \mathrm{~h}$ at room temperature, filtered and the final $\mathrm{pH}$ for each sample was determined. 


\section{IR analysis}

Infrared Spectroscopic (IR) spectra were taken to know the chemical bonding or molecular structure of organic or inorganic materials. Samples for IR analysis were prepared with the biomass loaded with and without metal solutions such as 100ppm and 400ppm for each species. Spectra were taken using IR-AVATAR 330 (Central Laboratory, Faculty of Science, Cairo University) in order to investigate the functional groups and the possible metal binding sites present in the $S$. platensis and $C$. vulgaris samples.

\section{SEM Analysis}

For Scanning Electron Microscopic the Samples coated by gold sputter coater (SPI- Module).The samples exanimate by scanning electron microscopy (JEOL-JSM-5500LV) by using high vacuum mode at the Regional Center of Mycology and Biotechnology, Cairo, Egypt. Samples studies were prepared with biomass treated with and without metal solution. SEM analysis was used to study the morphological changes of $S$. platensis and $C$. vulgaris.

\section{Results and Discussion}

The effect of $\mathrm{pH}$ value on the biosorption of iron ions onto S. platensis and $C$. vulgaris biomass was evaluated and the results were presented in Table (1). It is clear that the maximum biosorption for iron reached 67.5 and $75 \%$ at $\mathrm{pH}$ 6 and 8, respectively for S. platensis while C. vulgaris recorded 52.5 and $54.5 \%$ at $\mathrm{pH} 4$ and 6. On the other hand, S. platensis recorded 45.5 and $40 \%$ at $\mathrm{pH} 2$ and 4 , also $C$. vulgaris recorded 44.2 and $37.5 \%$ at $\mathrm{pH} 2$ and 8.The current results indicated that the biosorption of iron was increased with increasing the $\mathrm{pH}$ value for two species. This is because, at lower $\mathrm{pH}$, the concentration of positive charge (protons) increased on the sites of biomass surface, which restricted the approach of metal cations to the surface of biomass because of charge repulsion (Kaewsarn, 2002).

Table (1): Effect of pH on the biosorption of iron (at concentration $200 \mathrm{ppm}$ ) by $S$. platensis and $C$. vulgaris biomass.

\begin{tabular}{|c|c|c|c|c|}
\hline \multirow{2}{*}{ pH } & \multicolumn{2}{|c|}{ Final Iron Concentration (ppm) } & \multicolumn{2}{c|}{$\begin{array}{c}\text { Removal Efficiency } \\
(\%)\end{array}$} \\
\cline { 2 - 5 } & S. platensis & C. vulgaris & S. platensis & C. vulgaris \\
\hline 2 & 109 & 111.5 & 45.5 & 44.2 \\
\hline 4 & 120 & 95 & 40 & 52.5 \\
\hline 6 & 65 & 91 & 67.5 & 54.5 \\
\hline 8 & 50 & 125 & 75 & 37.5 \\
\hline
\end{tabular}


As the $\mathrm{pH}$ increase, the proton concentration decreases and the biomass surface is more negatively charged. The biosorption of the positively charged metal ions increased till reaching their maximum biosorption around $\mathrm{pH} 6$ and 8 for $S$. platensis and $\mathrm{pH} 4$ and 6 for $C$. vulgaris. This could probably correlate to the different characteristics between the two species of algae iron affinity to the surface functional groups of the cell wall is higher S. platensis than $C$. vulgaris at high $\mathrm{pH}$ value affinity to the algal biomass, and their binding mechanism include a combination of ion exchange, chelation, and reduction reactions, accompanied by metallic iron precipitation on the cell wall matrix.

The data presented in Table (2) showed the effect of metal concentration on biosorption process. The concentration of iron was varied between 100 and $400 \mathrm{ppm}$ at the optimum $\mathrm{pH}$ (6 for $C$. vulgaris and $\mathrm{pH} 8$ for $S$. platensis). The results presented in Table (2) indicated that the biosorption of iron at the beginning was $71.6,67.5,51.5$ and $24.67 \%$ respectively for $S$. platensis. On the other hand, C. vulgaris recorded 61.6, 54.5, 46.8 and 42.9\% respectively. The biosorption was decreased with increasing the metal concentration. This behavior was attributed to the fact that, initially, all binding sites on the biomass surface were vacant resulting in high metal biosorption at the beginning. After that, with increasing metal concentration, the biosorption of metal was decreased because of a few active sites were available on the surface of the algal biomass.

Table (2): Effect of initial iron concentration on iron removal efficiency by $S$. platensis and $C$. vulgaris biomass

\begin{tabular}{|c|c|c|c|c|}
\hline \multirow{2}{*}{$\begin{array}{c}\text { Initial Iron } \\
\begin{array}{c}\text { Concentration } \\
(\mathbf{p p m})\end{array}\end{array}$} & \multicolumn{2}{|c|}{$\begin{array}{c}\text { Final Iron Concentration } \\
(\mathrm{ppm})\end{array}$} & \multicolumn{2}{c|}{$\begin{array}{c}\text { Removal Efficiency } \\
(\%)\end{array}$} \\
\cline { 2 - 5 } & S. platensis & C. vulgaris & S. platensis & C. vulgaris \\
\hline 100 & 28.4 & 38.4 & 71.6 & 61.6 \\
\hline 200 & 65 & 91 & 67.5 & 54.5 \\
\hline 300 & 154.6 & 159.5 & 51.5 & 46.8 \\
\hline 400 & 301.7 & 228.6 & 24.67 & 42.9 \\
\hline
\end{tabular}

The results illustrated in Fig. (1 A, B and C) showed the IR spectra of the unloaded biomass and iron-loaded biomass. These results represented the information about the functional groups (like sulphonic, carboxylic (fatty acids and amino acids), phosphate, amid and hydroxyl (polysaccharide). Campanella $\boldsymbol{e t}$ al. (1998) studied Spirulina platensis surface cell wall biomass and the possible interaction between metals and the functional groups. From these data, of figure (1A) it is clear that the strong and broad band's at 3961, 3263, 3205 and $3166 \mathrm{~cm}^{-}$ ${ }^{1}$ might be related to the overlapping between $\mathrm{NH}$ and $\mathrm{OH}$ stretching vibration. Where the band at $3062 \mathrm{~cm}^{-1}$ could be related to the $\mathrm{CH}$ stretch and the band 1900 $\mathrm{cm}^{-1}$ could be the aliphatic group. Band at $1400 \mathrm{~cm}^{-1}$ related to the $\mathrm{CH}_{3}$, also band at

Egyptian J. of Phycol. Vol. 13, $2012 \quad$ - 125 - 
$1169 \mathrm{~cm}^{-1}$ could be assigned to asymmetric stretching vibration of CO. On the other hand, the intense and strong band at $617 \mathrm{~cm}^{-1}$ might be attributed to the stretching of $\mathrm{CH}$ group on the surface of the biomass (Sari and Tuzen, 2008). Meanwhile, some bands in the fingerprint region could be related to the phosphate groups. It could be observed that the bands at3961, 3263, 3205 , 3166, $3062,1900,1169$ and $617 \mathrm{~cm}^{-1}$ were changed to $3946,3278,3220,3067,3024$, $3004,1627,1415,1384$ and $613 \mathrm{~cm}^{-1}$ after loading of iron at 100ppm concentration Fig.(1 B) and 3988, 3938, 3911, 3379, 3321, 3305, 3197, 1620, 1388, 1265,1107 and $609 \mathrm{~cm}^{-1}$ after loading of iron at $400 \mathrm{ppm}$ concentration Fig.(1 C). It was observed that the new bands at466 $\mathrm{cm}^{-1}$ in Fig. $(1 \mathrm{~B})$ and bands at 597, 470, $432 \mathrm{~cm}^{-1}$ respectively in Fig. (1C) it could be presence of the metal (iron).The significant changes in the wave number of these peaks after loading of iron indicate that the functional groups (amido, hydroxyl and $\mathrm{CO}$ ) were involved in the biosorption of iron on the surface of $S$. platensis.
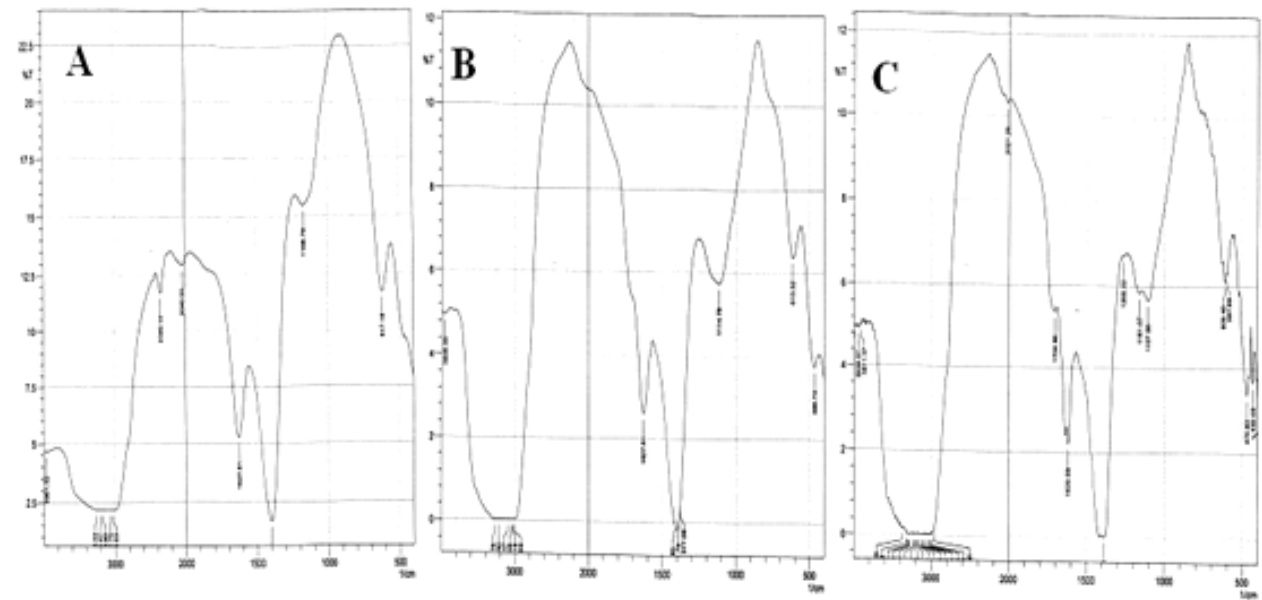

Figure (1): Spirulina platensis: A- Control; B- 100ppm iron concentration; C- 400ppmiron concentration

On the other hand, Figure ( $2 \mathrm{~A})$ show that the strong and broad band's $3942,3550,3861,3838,3205$ and $3093 \mathrm{~cm}^{-1}$ related to the $\mathrm{OH}$ group and band at $2345 \mathrm{~cm}^{-1}$ could be related to the $\mathrm{CH}$ stretch while band at $1631 \mathrm{~cm}^{-1}$ related to the $\mathrm{CH}_{3}$ group and band at $1168 \mathrm{~cm}^{-1}$ it could be $\mathrm{CN}$ group finally band at $632 \mathrm{~cm}^{-}$ ${ }^{1}$ might be attributed to the stretching of $\mathrm{CH}$ group on the surface of the biomass of C. vulgaris. New bands appear at 408 and $466 \mathrm{~cm}^{-1}$ after load by iron at $100 \mathrm{ppm}$ Fig. (2 B) and at 424, $470 \mathrm{~cm}^{-1}$ at 400 ppm of iron Fig.(2 C).

FTIR analysis led Ting et al., (1995) to suggest the involvement of carboxyl groups in binding of $\mathrm{Ag}$ (III) on Chlorella vulgaris. Participation of carboxyl groups in adsorption of $\mathrm{Cu}, \mathrm{Cd}$ and $\mathrm{Pb}$ on cyanobacterial cell wall has 
also been demonstrated (Yee $\boldsymbol{e t}$ al., 2004). According to Greene $\boldsymbol{e}$ t al. (1986) amino group plays an important role in binding of $\mathrm{Ag}$ to $C$. vulgaris as pretreatment of the alga with succinic anhydride that is known to react with amino groups making them unavailable for metal binding, resulted in a significant (50\%) decrease in Ag binding.
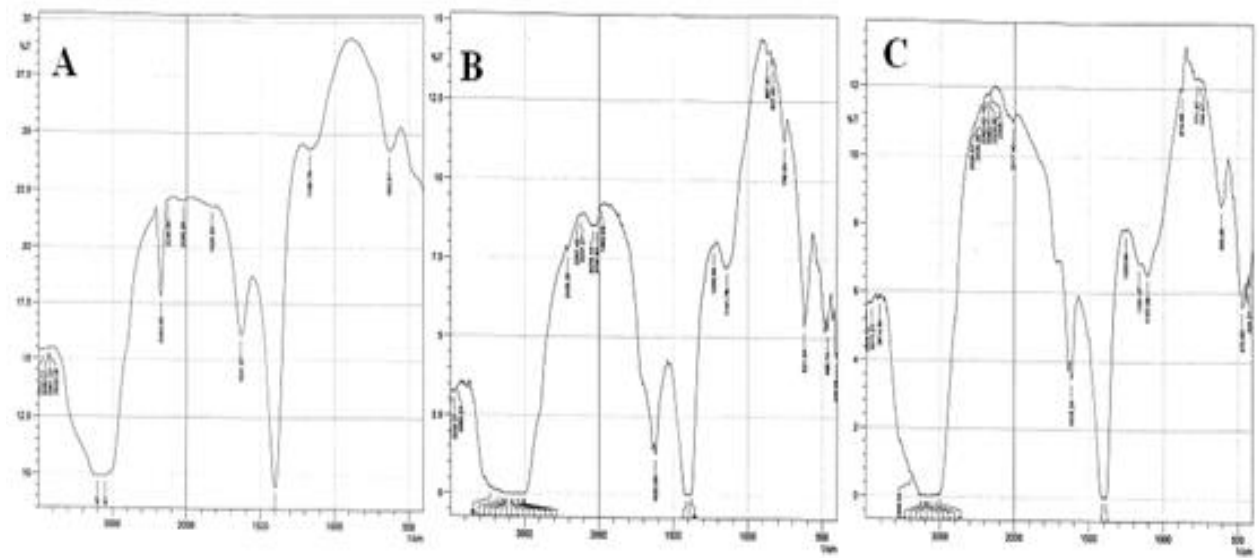

Figure (2): Chlorella vulgaris: A- Control; B- 100ppm iron concentration; C- 400ppm iron concentration

Based on IR spectra analysis, the most dominant role in the binding play the carboxyl groups from proteins and carboxylated polysaccharides Fang $\boldsymbol{e t}$ al. (2011). These groups have the highest affinity for metal ions because they are deprotonated in the $\mathrm{pH}$ range of the highest adsorption. Other groups, such as phosphate, hydroxyl and amino groups present in the surface area of alga cells can play only a minor role. Gong et al. (2005) concluded that amino and hydroxyl groups play a predominant role at high $\mathrm{pH}$ in binding of $\mathrm{Pb}$ on Spirulina maxima.

It is well documented that the $\mathrm{pH}$ of the aqueous solution affects the metal solubility and the concentration of the counter ions on the functional group of the cell wall of the biosorbent. Consequently, the $\mathrm{pH}$ is considered as the most important parameter that could affect the biosorption of metal ions from solutions (King et al., 2007; Gaur and Dhankhar, 2009).

\section{Scanning electron microscope}

SEM photographs of the samples are shown in Plate (1) S. platensis filaments some morphological changes when exposed to iron solution at low concentration showed electron dense metal are adsorbed on the cell wall (Plate 1B). While at high concentration (400ppm) there is the possibility of transport of these ions into transport cell membrane (Plate 1C). After sometime, S. platensis filament disintegration into separated cells as shown in Plate (1D). 
Plate (1)
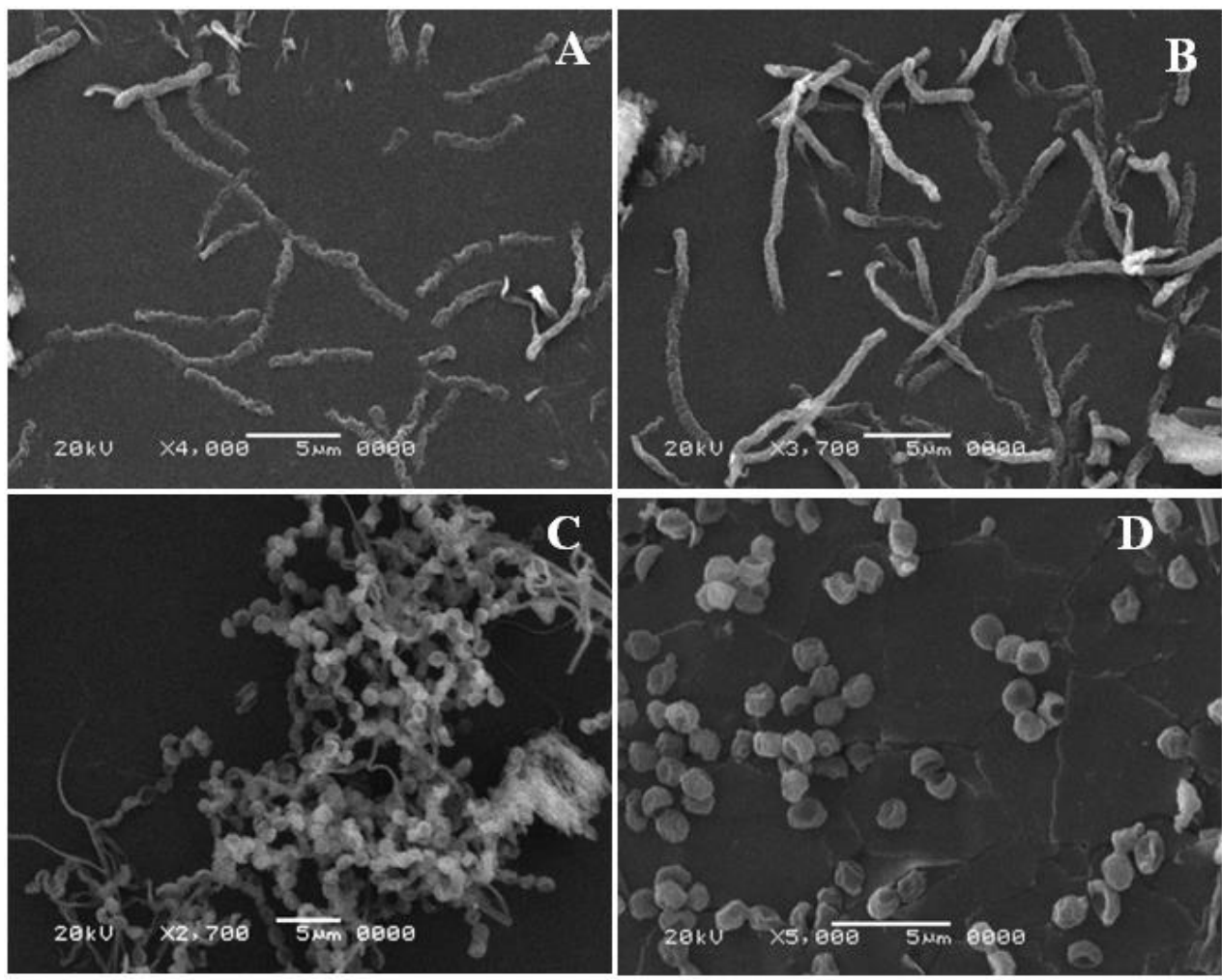

Spirulina platensis: A- Control; B- 100ppm iron concentration; C and D- 400ppm iron concentration

On the other hand SEM photographs of Chlorella vulgaris was shown in Plate (2). It revealed the change of surface morphology of biomass cell treated with metal ions at low concentration showing cells enlargement and surface modification of cell showed in Plate (2B). At high concentration crystallization was appear as precipitations on cell wall (Plate $2 \mathrm{C}$ and D). Tamilselvan $\boldsymbol{e t}$ al. (2011) reported the change in surface morphology of Acanthopora spicifera biomass treated with $\mathrm{Cr}$ metal ion, they found that the change in morphological characterization of seaweeds after interaction with chromium, size enlargement and surface modification. Doshi et al. (2007) demonstrated that the width of the filament of live Spirulina sp. varies from 2.00 to5 $\mu \mathrm{m}$ and expected the cell shrinks when it is dried, in dry species the surface of the biomass becomes rough after metal uptake. When treated with $\mathrm{Cd}^{+2}$ metal ion there is possibility of transport of these ions through the cell membrane of biomass. 
Plate 2

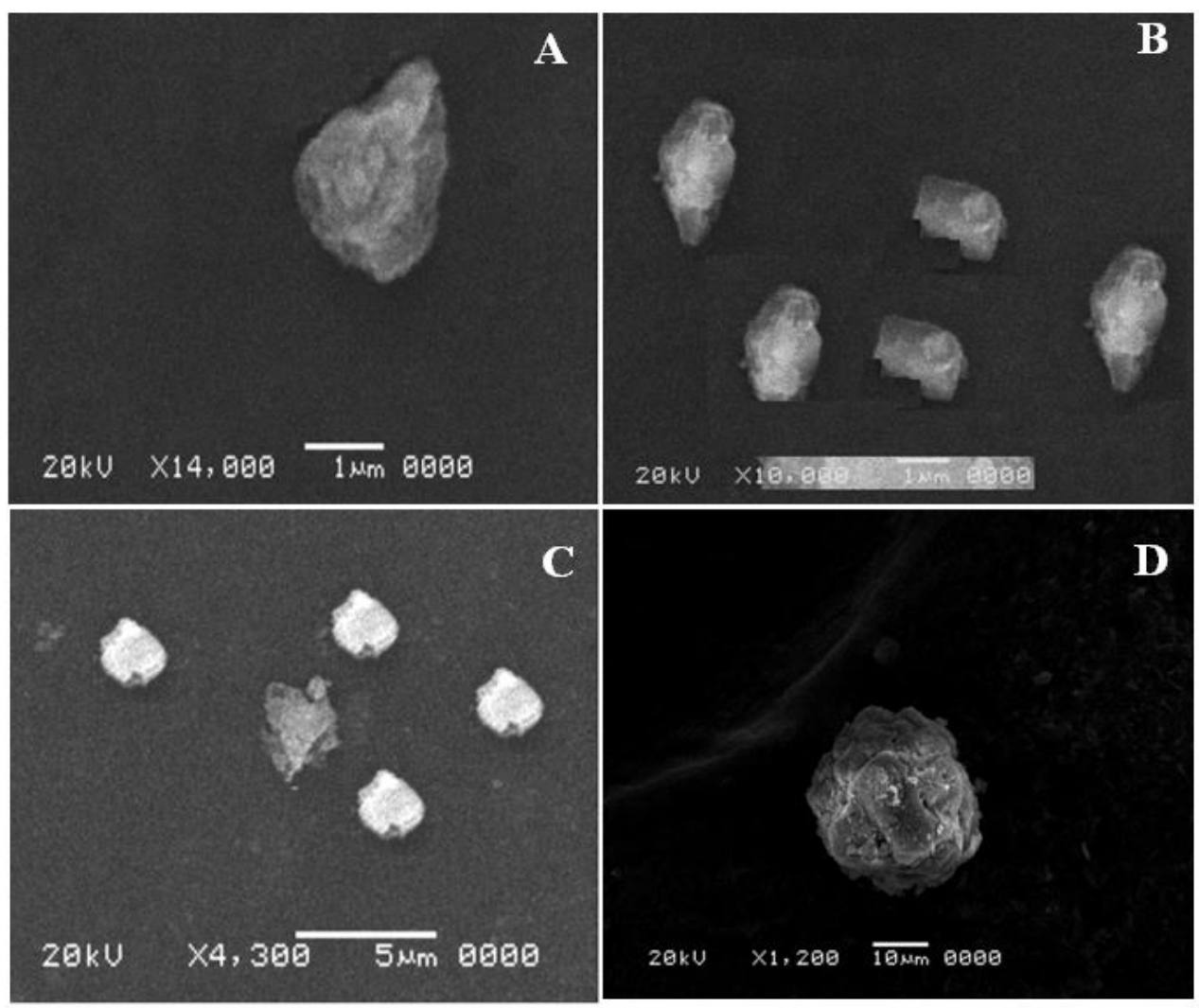

Chlorella vulgaris: A- Control; B- 100ppm iron concentration; C and D- 400ppmiron concentration

\section{Conclusions}

Our results demonstrated that the use of dead cells of $S$. platensis and $C$. vulgaris for biosorption of iron. The maximum biosorption capacities were $75 \%$ for $S$. platensis at $\mathrm{pH} 8$ and $54.5 \%$ for $C$. vulgaris at $\mathrm{pH}$ 6.The IR indicated that the amino, carboxyl, hydroxyl and carbonyl groups on the surface of the biomass are responsible for biosorption of iron. This work will be helpful in developing technologies useable for bioremediation using S. platensis and C. vulgaris.

\section{References}

Abu Al-Rub, F. A.; El-Naas, M. H.; Ashour, I. and Al-Marzouqi, M. (2006). Biosorption of copper on Chlorella vulgaris from single, binary and ternary metal aqueous solutions. Process Biochemistry, 41:457-464.

Aksus, Z. and Gulen, H. (2002). Binary biosorption of iron-cyanid complex ions on Rhizopus arrhizus: modeling of synergistic interaction. Process Biochemistry, 38:161-173. 
Anayurt, R. A.; Sari, A. and Tuzen, M. (2009). Equilibrium, thermodynamic and kinetic studies on biosorption of $\mathrm{Pb}$ (II) and $\mathrm{Cd}$ (II) from aqueous solution by macrofungus (Lactarius scrobiculatus) biomass. Chemical Engineering Journal, 151:255-261.

APHA (American Public Health Association) (2005). Standard Methods for the Examination of Water and Wastewater, $21^{\text {th }}$ (ed.) American Public Health Association, American Water Works Association, Water Environment Federation, Washington, DC.

Campanella, L.; Cresentini, G.; Avino, P. and Moauro, A. (1998). Determination of macrominerales and trace elements in the alga Spirulina platensis. Analusis, 26:210-214.

Çelekli, A.; Yavuzatmaca, M. and Bozkurt, H. (2010). An ecofriendly process: predictive modeling of copper adsorption from aqueous solution on Spirulina platensis. Journal of Hazardous Materials, 173:123-129.

Doshi, H.; Ray, A. and Kothari, I. L. (2007). Biosorption of cadmium by live and dead Spirulina: IR spectroscopic, kinetics, and SEM studies. Current Microbiology, 54: 213-218.

El-Sheekh, M. M.; El-Shouny, W. A.; Osman, M. E. H. and El-Gammal E. W. E. (2005). Growth and heavy metals removal efficiency of Nostoc muscorum and Anabaena subcylindrica in sewage and industrial wastewater effluents. Environmental Toxicology and Pharmacology, 19:357-365.

EPA (Environmental Protection Agency) (2000). Wastewater Technology Fact Sheet Chemical Precipitation. United States Environmental Protection Agency, Office of Water Washington, D.C., 832- F-00-018.

Fang, L.; Zhou, C.; Cai, P.; Chen, W.; Rong, X.; Dai, K.; Liang, W.; Gu, J.D. and Huang, Q. (2011). Binding characteristics of copper and cadmium by cyanobacterium Spirulina platensis. Journal of Hazardous Materials, 190(1):810-815.

Gadd, G. M. (1993). Interactions of fungip with toxic metals. New Physiologist, 124:25-60.

Gaur, N. and Dhankhar, R. (2009). Equilibrium modeling and spectroscopic studies for the biosorption of $\mathrm{Zn}^{+2}$ ions from aqueous solution using immobilized Spirulina platensis. Iranian Journal of Environmental Health, Science and Engineering, 6(1):1-6.

Gokhale, S. V.; Jyoti, K. K. and Lele, S. S. (2008). Kinetic and equilibrium modeling of chromium (VI) biosorption on fresh and spent Spirulina platensis/Chlorella vulgaris biomass. Bioresource Technology, 99(9):3600-3608.

Gong, R.; Ding, Y.; Liu, H.; Chen, Q. and Liu, Z. (2005). Lead biosorption and desorption by intact and pretreated Spirulina maxima biomass. Chemosphere, 58:125-130. 
Greene, B.; Henzl, M. T.; Hosea, J. M. and Darnall, D.W. (1986). Elimination of bicarbonate interference in the binding of U(VI) in mill-waters to freeze-dried Chlorella vulgaris. Biotechnology and Bioengineering, 28(5):764-767.

Gupta, V. K. and Rastogi, A. (2008a). Biosorption of lead (II) from aqueous solutions by non-living algal biomass Oedogonium sp. and Nostoc sp. a comparative study. Colloids Surfaces B: Biointerfaces, 64:170-178.

Gupta, V. K. and Rastogi, A. (2008b). Biosorption of lead from aqueous solutions by green algae Spirogyra species: kinetics and equilibrium studies. Journal of Hazardous Materials, 152:407-414.

Gupta, V. K. and Rastogi, A. (2009). Biosorption of hexavalent chromium by raw and acid-treated green alga Oedogonium hatei from aqueous solutions. Journal of Hazardous Materials, 163:396-402.

Holan, Z. R. and Volesky, B. (1994). Biosorption of lead and nickel by biomass of marine algae. Biotechnology and Bioengineering, 43:1001-1009.

Iyer, A.; Mody, K. and Jha, B. (2005). Biosorption of heavy metals by a marine bacterium. Marine Pollution Bulletin, 50 (3):340-343.

Kaewsarn, P. (2002). Biosorption of copper (II) from aqueous solutions by pretreated biomass of marine algae Padina sp. Chemosphere, 47:10811085.

King, P.; Rakesh, N.; Beenalahri, S.; Kumar, P. and Prasad, V. S. R. K. (2007). Removal of lead from aqueous solution using Syzygium cumini L.: equilibrium and kinetic studies. Journal of Hazardous Materials, 142:340-347.

Mamisahebei, S.; Khaniki, G. R. J.; Torabian, A.; Nasser, S. and Naddafi, K. (2007). Removal of arsenic from an aqueous solution by pretreated waste tea fungal biomass. Iranian Journal of Environmental Health, Science and Engineering, 4: 85-92.

Mehta, S. K. and Gaur, J. P. (2001). Characterization and optimization of N and $\mathrm{Cu}$ sorption from aqueous solution by Chlorella vulgaris. Ecological Engineering, 18:1-13.

Ncibi, M. C.; Mahjoub, B. and Seffen, M. (2007). Adsorptive removal of textile reactive dye using Posidonia oceanic (L.) fibrous biomass. International Journal of Environmental Science and Technology, 4(4):433-440.

Picardo, M. C.; Ferreira, A. C. and Dacosta, A. C. (2009).Continuous thorium biosorption - Dynamic study for critical bed depth determination in a fixed-bed reactor. Bioresource Technology, 100:208-210.

Roy, D.; Greenlaw, P. N. and Shane, B. S. (1993). Adsorption of heavy metals by green algae and ground rice hulls. Journal of Environmental Science and Health, Part A, 28:37-50.

Sari, A. and Tuzen, M. (2008). Biosorption of $\mathrm{Pb}$ (II) and Cd (II) from aqueous solution using green alga (Ulva lactuca) biomass. Journal of Hazardous Materials, 152:302-308.

Egyptian J. of Phycol. Vol. 13, $2012 \quad$ - 131 - 
Schiewer, S. and Volesky, B. (1995). Modeling of the Proton-Metal Ion Exchange in Biosorption. Environmental Science and Technology, 29(12):3049-3058.

Sen, M. and Ghosh Dastidar M. (2007). Biosorption of Cr (VI) by resting cells of Aspergillus sp. Iranian Journal of Environmental Health, Science and Engineering, 4(1):9-12.

Solisio, C.; Lodi, A.; Torre, P.; Converti, A. and Del Borghi, M. (2006). Copper removal by dry andre-hydrate biomass of Spirulina platensis. Bioresources Technology, 97(14): 1756-1760.

Tamilselvan, N.; Saurav, K. and Kannabiran, K. (2011). Biosorption of selected toxic heavy metals using algal species Acanthopora spicefera. Pharmacologyonline, 1:518-528.

Ting, Y. P.; Teo, W. K. and Soh, C. Y. (1995). Gold uptake by Chlorella vulgaris. Journal of Applied Phycology, 7:97-100.

Tunali, S.; Akar, T.; Ozcan, A.S.; Kiran, I. and Ozcan, A. (2006). Equilibrium and kinetics of biosorption of lead (II) from aqueous solutions by Cephalosporium aphidicola. Separation and Purification Technology, 47 (3):105-112.

Yee, N.; Benning, L. G.; Phoenix, V. R. and Ferris, F. G. (2004). Characterization of metal-Cyanobacteria sorption reactions: A combined macroscopic and infrared spectroscopic investigation. Environmental Science and Technology, 38:775-782.
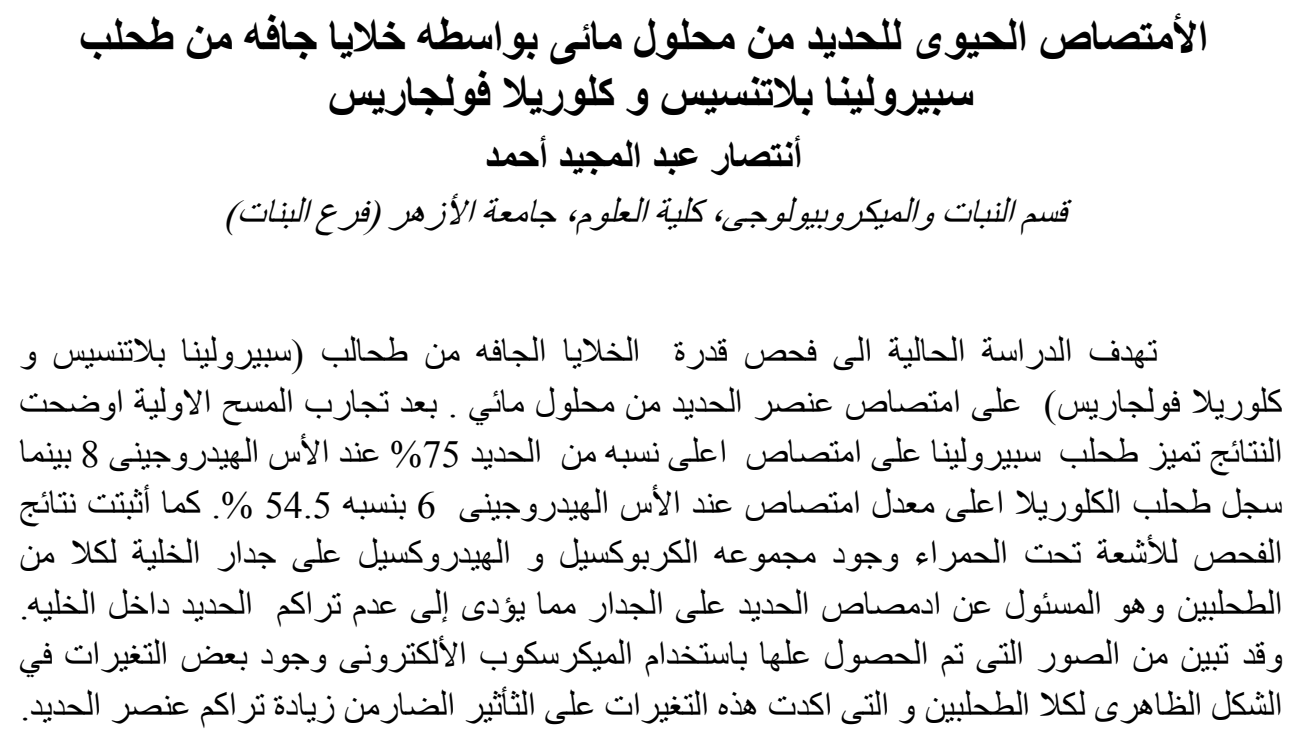